\title{
THE EFFECT OF GRAPHIC ORGANIZER WITH SCHOOLOGY ON STUDENTS' WRITING SKILL AT MA MASYHUDIYAH GIRI
}

\author{
Betty Indah Cahyaningtias ${ }^{1}$, Khoirul Anwar ${ }^{2}$, Ulfatul Ma'rifah ${ }^{3}$ \\ University of Muhammadiyah Gresik ${ }^{1}$ \\ cahyanningtiass@gmail.com \\ University of Muhammadiyah Gresik ${ }^{2}$ \\ khoirulanwar@umg.ac.id \\ University of Muhammadiyah Gresik ${ }^{3}$ \\ ulfamarifah@umg.ac.id
}

\begin{abstract}
Writing is a productive skill which makes the students managing the ideas into texts or paragraphs. Writing skill is one of the things that noticed by the Indonesian Minister of Education and Culture. It can be seen at the curriculum. The curriculum expects that the students will be able to write in English texts well at the end of learning process. However to reach the goal at curriculum is not easy. It because the students have a lot of problems in learning writing. For instance, when the students write paragraph, they usually has no unity so the content of each paragraph did not appropriate with the topic. Then, the students difficult to organize ideas properly. Besides that, the students also difficult to choose the appropriate words. These problems are caused by the ways students learn writing are not really effective. To solve the problems, the researcher use Graphic Organizer with Schoology as the alternative in teaching writing. This study was investigate the significant effect of Graphic Organizer with Schoology on Students' Writing Skill. The researcher chose eleventh grade at MA Masyhudiyah Giri to conduct this study. The sample was 11 MIPA 2 as the experimental group and 11 MIPA 3 as the control group. Both of class consisted of 30 students. So, the number of the participants in this study was 60 students. The research finding showed that there was a signinificant difference between experimental group who were taught by using graphic organizer with schoology and control group who were taught by only using graphic organizer. It is proven by the result of sig. (2-tailed) is lower than $0.05(0.000<0.05)$. So, the null hypothesis can be rejected. It means that Graphic Organizer with Schoology has significantly effects on students' writing skill. Therefore, the researcher suggest to the English teacher for Implementing of Graphic Organizer with Schoology as the alternative in teaching writing. For the future researcher, the researcher hopes that can use Graphic Organizer with Schoology in different way to develop other skill such as reading skill to make a difference with this study.
\end{abstract}

Keywords : Writing Skill, Graphic Organizer, Schoology

\section{INTRODUCTION}

Writing skill in learning English is one of the things that noticed by the Indonesian Minister of Education and Culture. It can be seen from the latest curriculum in Indonesia namely 2013 curriculum, writing is one of the goals in learning English. The curriculum expects that the students will be able to write or express their ideas in English texts well at 
the end of learning process, in this curriculum requires the students to be productive (Inayah \& Nanda, 2016). It can be seen from the Standard Competence at X1 Grade in syllabus of 2013 curriculum "Capturing the meaning and arranging oral and written texts, by using the sequential and coherent text structure and also accurate linguistic elements, acceptable and fluent" (Depdiknas, 2013). To achieve those curriculum expectations, the teaching of writing at high school levels teach the students a variety of English text types, such as invitation text, letter, analytical exposition text, report text, biography text, narrative text, and many other functional types of texts.

However to reach the goal in curriculum is not easy. It is because the students have problems in the writing class. A study conducted by Za'in (2017) aimed to finding out the students problem in writing and the result showed that beside grammatical use problem, the serious issue in writing problems are organization, content and lack of vocabulary. In the problem of organization, the students difficult to organize the ideas, the consequence is the students write paragraph without consist of the complete generic structure of the text. After that, in the problem of content the students did not compose their writing coherently. In this case the student write paragraph which has no unity. Here the researcher found that the content of each paragraph from the students did not appropiate with the topic and also the title does not suitable with the content or paragraph. Then, in the term of lack vocabulary, the problem here is the students write incorrect and inappropiate words in their sentences.

In addition Inayah \& Nanda (2016) did the same research, their study aimed to finding out the difficulties in writing faced by the students' at senior high school. The result is similiar with the previous study. Organization, content and vocabulary become the issue which should be attention in writing problems. In the term of organization, the students get confused on how to organize ideas properly and to link ideas between paragraphs. Then in the aspect of content, the students had difficulties in developing his ideas. The students were unable to elaborate the main idea by using supporting details in one paragraph. After that, in the vocabulary, the students tended to choose words which were not suitable for the context. So here, the students had difficulty in choosing appropriate words to make sentences.

Other than that, Novariana, Sumardi, Tarjana (2018) also investigate the students' problems at the one of senior high school in Indonesia. The result also showed the similar like the previous studies above. The first problems is the students 
difficulty to choose the appropriate words in writing, this is because the students have a lack of vocabulary. Then, the second is the students have difficulty to arrange words in the appropriate order. Here the students have problems in structuring paragraph, topic development of a paragraph, structuring the whole discourse and a theme in a discourse, differentiating a topic and supporting ideas or generalizations and specific details.

Based on the previous studies above, the researcher concluded that the students have a problem in the three aspects of writing, among others are problem in organization which include of the students difficult to organize ideas properly, then problem in content which include of the students write paragraph which has no unity so the content of each paragraph did not appropriate with the topic and the last is problem in vocabulary, here the students difficult to choose the appropriate words. These problems are caused by the ways students learn writing are not really effective. Writing is perceived as a way to communicate thoughts (Berry et.al, 1999). That's why the teacher need a strategy which can give the students a chance to logically sequence his or her ideas in their thoughts while maintaining focus on a main topic. This is supported by Mukminatien as cited in Miftah (2015b, p. 9) said that the difficulties are not merely caused by the students themselves but it also can come from the strategy or techniques that the teacher used. In addition, to achieve effective writing learning, the teacher as a mentor must be able to apply the learning process to the maximum (Rahmatullah, 2016). The one of solution to make the maximum in learning process is making the students become active learners. So that the students don't tend to only act as a listener, but they can explore their learning process. The students active involvement as a good way is supported by Hidayah (2016) who said that participation or learning involvement from the students is very necessary to achieve a good learning process. Therefore students must be actively involved in the learning process at school.

One of strategy that is effective to support students' writing skill is using Graphic Organizer with Schoology. It because some researchers had conducted the studies to know the effect of graphic organizer on students' writing skill and the result was graphic organizer had possitive effect to the students and some experts also said the same thing about schoology. Graphic organizer can make the students' writing become better. Graphic organizers helped the students organize their thoughts, helping them select the main ideas and supporting details. In addition schoology also had the good impact for students 
writing skill. This is because according to Çepik, Gönen and Sazak (2016) as the learning management system, schoology provide the teachers tools to upload materials and information related to the topic in various formats such as audio files, images, videos, and links that can facilitate the teacher to give the material and allows the teacher to design the learning process to be creative. Schoology also make the students become active learners.

The following are some previous research about graphic organizer. First, a study conducted by Mahmudah \& Jamilah (2015), they investigated the use of graphic organizer to improve students' writing skill. The findings showed that the students' writing skills were improved after the implementation of graphic organizer in writing process.

The students' improvement could be seen from the data. Their writings had a well organized than before. Here the students organize their ideas properly. The content of their writing was acceptable and relevant since they could develop the ideas well in the form of graphic organizer, but from this study, the researcher found that there is a problem in the students' by using graphic organizer namely the students needed much information to complete the graphic organizer. This is because they had limited information about the topic given in the task.
Then, a study conducted by Irawati et.al (2014) their reseach aimed to investigated the use of sandwich graphic organizer to improve the writing ability. The findings of this study showed that graphic organizer help the students to increase their writing skill. Through graphic organizer the students be able to write with good organization. Here the students can arrange the words in appropriate order. Then, graphic organizer is also help the students in improving their content on writing. The content from the students writing here more directed and unity. Other than that, here the students be able to write with appropiate words in their sentences too. But in this study also found the same problem with the previous study. The students have difficulty to fill the graphic organizer. This is because graphic organization only help students to separate what is important to know but not give the students information. The information here is related to the topic or theme who students will write. That's why to make a strategy become better it can be supported one of the media that can be used in teaching writing to help the students get information in graphic organizer (El-Muslimah, 2016).

In addition a study conducted by Tayib (2015) investigated the effect of using graphic organizer on students' writing ability. The result showed that using graphic organizer had significantly 
improved the students' writing ability. Participants' mean score in writing increased from 45.00 in pre-test to 68.88 in post-test. The students' writing improve especially in the aspect of content, organization and word choice. But here graphic organizer didn't presented in a creative way. That's why the researcher Tayib (2015) recommended using graphic organizer in modern way such as using technology needs to be explored and investigated, because these could be a better alternative to make the students writing get better at this modern time of globalization era.

According to the previous studies related the use of graphic organizer on students' writing skill it can be seen that there is a problems in using graphic organizer, namely the students feel difficult to fill the graphic organizer because they had limited information about the topic. Besides that, the previous research has recommendation to implement graphic organizer in modern way such as using technology because nowadays technology has become part of our life that can support and transform education in a good way. Here the researcher combine Graphic Organizer with Schoology. It because according to the Mutia (2018) schoology has possitive impact in writing skill. Schoology has the feature to upload videos or image so it can help the writer find the information about the topic that they will write when they had limited knowledge about that. It also help the students to activate background knowledge about the topic before fill their graphic organizer. In addition Greenhow, Robelia, \& Hughes (2009) also added that schoology is more favorable to students. Because schoology has a great feature. One of the features is resources. In the resources feature, the students can draw there. So it can support the students to design their own graphic organizer with various shapes and colors. Furthermore, Ardi, P. (2017) has a recommendation to use Schoology in English language learning and teaching because schoology can make the students actively involved in the learning process and can give the students meaningful and relevant English learning experiences in the 21 st century.

Based on the explanation above, the researcher interested to combine Graphic Organizer Strategy with Schoology media to find out whether applying the combination both of them will have a positive effect on students' writing skill at MA Masyhudiyah Giri.

\section{REVIEW OF \\ RELATED \\ LITERATURE \\ Writing Skill}

Writing is categorized as a productive skill who has many aspects such 
as content, grammar, vocabularies, organizing idea, mechanic and styles. Then based on Matthews (2000: 1560), the definition of writing is produce something in written form and then people can read, do or use it. Furthermore according to Atta \& Salem, 2013 writing is one of the most difficult to master language skills. This is because writing is obtained more slowly than speaking. For example: the first thing a newborn baby does is cry, not write. Moreover, writing is not natural and it must be learned (Chaedar (2001: 3). Apart from that writing is not only producing and managing the ideas but also in translating the ideas into readable and understandable texts or paragraphs (Asrobi \& Prasetyaningrum, 2017).

Components of Writing :

According to Hughes (2008, p. 103), there are five components of writing that should be considered in writing text. They are as follows:
a. Content
b. Organization
c. Vocabulary
d. Language use
e. Mechanics

\section{Graphic Organizer}

According to Hall \& Strangman (2002) graphic organizer can be defined as visual or graphic displays that have a function to show the relationship between facts, terms or ideas. The function is to provides learners with a framework of information to learn. This is very useful for students because it can help direct students' attention to key concepts and conceptual relationships. In addition, graphic organizer also improve understanding. Then based on Sharrock (2008) and Emerson (2010) graphic organizer is strategy in writing which can help students to make a good topic sentence, supporting idea, supporting details, and concluding sentence so that students can write well and product the good written. Clark., Zaini et. al. (2010) add that graphic organizer is the strategy which not only help students to record and categorize information, but also help students to understand difficult concepts, generate thoughts, and identify connections between ideas. It makes the students easier to write.

The following sentences are the types of graphic organizers:

a. Sequence Chart

Sequence chart is the graphic that provides events start from the first till the end (Baxendell, Brad W, 2003). This organizer has function to help students understand the sequence of events in a process.

b. K-W-L charts

K-W-L charts are graphic organizers that help students organize information before, during, and after a unit or a 
teaching learning process. Based on Ogle (1986) KWL (Know, Want, Learn) is strategy in teaching learning which have a purpose to building the previous knowledge, establishing a purpose what is needed and for summarising what was learned.

c. Venn Diagram

This organizer has a function to help the students recognize the differences and/or similarities between to concept or more (Baxendell, Brad W, 2003).

d. Concept Map

A concept map is a graphical map that visualizing the relationship among concepts. This kind of graphic organizer help the writers to organize their ideas in a hierarchical order by setting the most general information at the top of the diagram and the most specific ones at the bottom and see how one concept is related to another concept (Novak and Cañas, 2008).

Based on the explanations above, there are many types of graphic organizers for teaching and learning, but in this research the researcher only focused on concept map to limit the study. It because one of the material in $11^{\text {th }}$ grade at the first semester is analytical exposition text and the researcher use that to her study, so here the researcher use concept map as the one of type graphic organizers. This is supported by Manoli \& Papadopoulou
(2012) who said that concept map is kind of graphic organizers that can be used in expository texts such as analytical exposition text.

\section{Schoology}

Schoology is a web-based educational application that allows the teachers to provide digital learning to students. Schoology can also be accessed for free. Besides that, for ease to use, Schoology adopted Facebook as an interface and feature (Manning et al., 2011, p. 26). In addition, to use this application in teaching and learning process, the students can access www.schoology.com on a computer or download Schoology on the PlayStore or Appstore on a smartphone. As the learning management system, schoology provide the teachers tools to upload materials in various formats such as audio files, images, videos, and links (Çepik, Gönen and Sazak, 2016). This online social learning network is quite widely used in the world of education. This is evidenced by data showed that there are more seven million users from more than $60,0000 \mathrm{~K}-12$ schools and higher education institutions around the world use this learning platform in their classrooms (Sarrab et al., 2016). 


\section{RESEARCH METHOD}

This research uses quantitative method, especially experimental research design to test the theory whether it gives significant effect or not in students' writing skill. An experimental design is chosen for this research because experiments provide answers for cause-effect relations (Abbott \& McKinney, 2013). More specifically, this study will use quasi experimental design. There are two variables in this study, among others are dependent variable and independent variable. Dependent variable is writing skill. While independent variables are graphic organizer and schoology. In this study there are two groups, namely experimental group and control group. The experimental group will be given treatment by using graphic organizer with schoology while control group will be given by only using graphic organizer.

\begin{tabular}{|c|c|c|c|}
\hline Group & $\begin{array}{c}\text { Pre- } \\
\text { test }\end{array}$ & Treatments & $\begin{array}{c}\text { Post- } \\
\text { test }\end{array}$ \\
\hline Experiment & $\mathrm{X}$ & $\mathrm{X}$ & $\mathrm{X}$ \\
\hline Control & $\mathrm{X}$ & - & $\mathrm{X}$ \\
\hline
\end{tabular}

Where:

+ : With treatment (Using graphic organizer with schoology)

- : Without treatment (Only using Graphic Organizer
From the table above, it can be seen that both of the groups will be given pre-test in the beginning of the research. The two groups will be taught with same topic but in different technique teaching. The experimental group will give the treatment by applying graphic organizer with schoology. Meanwhile, the control group will be taught by only using graphic organizer. After giving the treatment, the researcher will give post-test to both of groups, then the results will be compared with computed statistically.

\section{Population and Sample}

Population

The population of this study is students of $11^{\text {th }}$ grade at MA Masyhudiyah Giri which consist of 4 classes: three class of science and one class of social. The total number of the students in $11^{\text {th }}$ grade at MA Masyhudiyah Giri is 120 students.

Sample

For the sample of the study, the researcher will take two classes at $11^{\text {th }}$ grade in order to get the data. They are 11 MIPA 2 and 11 MIPA 3. Those are divided into two categorize, namely 11 MIPA 2 as the experimental group that will be taught by using graphic organizer with schoology. While 11 MIPA 3 as the control group that will be taught by only using graphic organizer. 


\begin{tabular}{|l|c|c|c|}
\hline No & Grade & Group & $\begin{array}{c}\text { Number of } \\
\text { Students }\end{array}$ \\
\hline 1. & $\begin{array}{c}11 \mathrm{MIPA} \\
2\end{array}$ & Experimental & 30 \\
\hline 2. & $\begin{array}{c}11 \mathrm{MIPA} \\
3\end{array}$ & Control & 30 \\
\hline \multicolumn{2}{|c|}{ Total number of the students } & 60 \\
\hline
\end{tabular}

\section{Data Collection}

Instrument

To obtine the data, the resaecher uses written test instrument. Furthermore, in this study, the research using pre-test and post-test. By using pre-test and post-test, researcher want to get information about the score of students writing in control group and experimental group. To get a score, the researcher using a scoring guide that chosen as an assessment criterion for aspect writing skills.

Pre-test

The researcher will give pre-test to control group and experimental group which is conducting before the treatment. So pre-test happened in the beginning of this study. The aim of pre-test is to find the information about the students' writing scores before the treatment. The researcher will give the different test between pre-test and post-test, but the tests are still equal in the term of material (analytical exposition text) and item. The differences is lies on the themes that will be written into analytical exposition text.
Post-test

The researcher will give post-test which is conducting after the treatment. The purpose of post-test is to find the information about the students' writing scores after given a treatment. In the post test the students will write the same material with the pre-test, namely analytical exposition text but the themes that the teacher will give to the students is different with the pre-test.

Validity of the Test

Validity is needed before give the students a test. The function is to measure the test to know it valid or not. Because validity is the one of requirement to produce the appropriate and useful in term of purpose of the test. The researcher uses content validity to analyse the test. According to Ary (1990) content validity can be determined by whether the test's items suitable with the subject and objectives in the curriculum guides, syllabus and course book so content validity is not always in numeric form.

In this study, the researcher will use content validity to guarantee the validity of test. The researcher compares the test based on curriculum and syllabus of Senior High School. If the test appropriate with curriculum and syllabus, it means that the test is valid so the test can give to the students. The test should be determine 
whether the items of the test represent objective or subjective item. This study include in subjective test, the content of validity will measured by relating the content of the instrumen with standard in Indonesia curriculum. The instrumen of this study is writing form which measured the ability of students' writing skill.

\section{Reliability}

Reliability refers to the consistency of assessment scores. In other words, reliability is the consistency of the measurement, or degree to which an instrumen measures the same way each time it is under the same condition. So the reliability in writing test is used to know whether the rubric is reliable or not. In writing test, rubric is the things that must be consistent and trusty. In this study the researcher adoption a rubric from Jacob (1981) to score students' writing skill.

\section{Procedure of Collecting Data}

In collecting data, the researcher has some procedures. The first step is researcher makes pre-test and post-test. The second is the researcher divides the subjects into two groups namely experimental and control group. After that, the researcher gives treatment to experimental group by using graphic organizer with schoology. Meanwhile, the control group will given the treatment by only using graphic organizer.
Then, the researcher gives post-test to both of groups. And the last step is analyzing the data from the pre-test and post-test by using SPSS 16.0 program.

\section{Data Analysis}

After conducting pre and post test, the researcher needs to analyze the result. The researcher identifies the progress of the students in writing skill due to the actions. The data will analyzed by quantitative. Quantitative test was carried out statistically using t-test. The researcher employed statistical program of SPSS to get rapid and accurate data calculation. The instrument that analyzed quantitatively is the results of pre-test and the post-test.

\section{Normality Distribution Test}

Normality distribution test is used to find out whether or not the data between two groups are normally distributed. The researcher uses normality distribution test because she wants to know the data between experimental group and control group toward writing skill are in normal distribution or not. To analyze it, this researcher uses Kolmogorov-Smirnov test in SPSS. If the Sig. is more than the level of significance $(0.05)$ the null hypothesis is accepted. It means that the score normally distributed. On the other hand, if the Sig. is less than the level of significance (0.05) the null hypothesis is rejected. 
Homogeneity Test

Homogeneity test is used to find out whether the research population has the same variance or not. The researcher also uses homogeneity test because she wants to know the variance between experimental group and control group toward writing skill are homogeneous or not. To analyze it, the researcher uses Lavene's test in SPSS.

\section{Hypothesis Testing}

In this study, the researcher uses independent t-test to know the significant difference between experimental group and control group is accepted or rejected. To calculate t-test, the researcher uses SPSS (Statistical Product and Service Solution). It is aims to find out the significance effect of Graphic Organizer with Schoology on studens' writing skill. After the scores were computed in SPSS 16.0, see the output of independent $\mathrm{t}$-test and interpreted the output that if sig (2-tailed) $>(0.05)$, the researcher should accept the $\mathrm{H}_{0}$ but if sig (2tailed $<(0.05)$, the researcher can reject $\mathrm{H}_{0}$, it means $\mathrm{H}_{1}$ is accepted.

\section{RESEARCH FINDING AND DISCUSSION}

\section{Research Findings}

In pre-experiment, the researcher took two classes of eleven grade at MA Masyhuhidiyah Giri as the sample, they were 11 MIPA 2 as the experimental group and 11 MIPA 3 as the control group. The researcher gave the treatment for both of groups for four times.The experimental group was given the treatment by using graphic organizer with schoology, while the control group was given the treatment by only using graphic organizer. The researcher has been conducted the pre test for both of experimental and control group. The test item is in form of writing test, so the researcher checked the content validity of the pre-test by analyzing the syllabus. In the pre-test, the researcher prepared four themes among others are Reading, Air Pollution, Rubbish and Early Marriage. After that, the teacher asked the students to choose one of the themes and then the students wrote an analytical exposition text based on the theme.

\section{Normality Testing}

In this study, the researcher used pre-test to know whether the data were in normal distribution or not. KolmogorovSmirnov test used to analyze the normality distribution both of experimental group and control group.

From the data above, it can be seen that the result of pre-test score from experimental group and control group were in normal distribution. The result of pre-test score from experimental group was Sig 0.200 where higher than the level of 


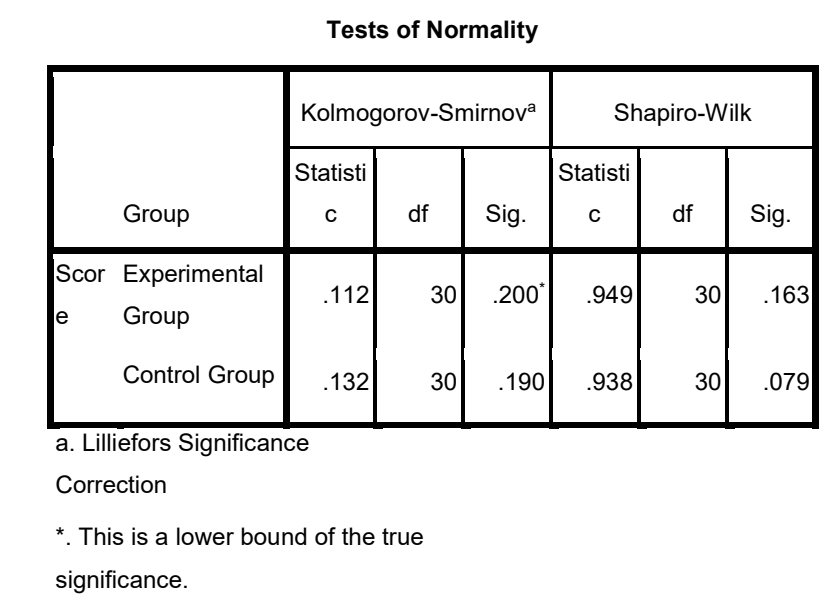

Independent Samples Test

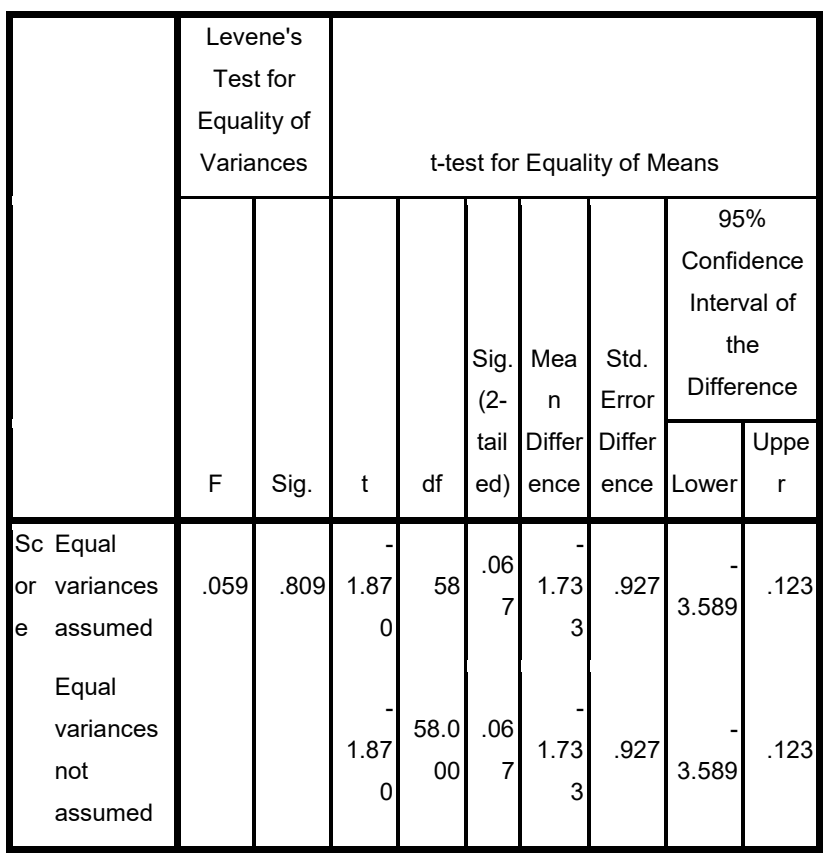

significance $0.05(0.200>0.05)$ and the result from pre-test score of control group was Sig 0.190 where higher than the level of significance $0.05(0.190>0.05)$. It showed that the pre-test scores from both two groups were in normal distribution.

\section{Homogeneity Testing}

In this study, the researcher also used pre-test to know whether the two groups have the same variance or not. The researcher analyze this homogeneity test by using Levene's test. The pre-test score of experimental group was 60.67 and the control group was 62.40. The result of independent semple t-test is showed in the following:

From the table above, the result of Levene's Test for Equality of Variances showed that $\mathrm{F}=0.059$ and the sig. $=0.809$ which means that there was no different variance between experimental group and control group because the sig. was higher than the level of the significance $0.809>0.05$. It means that both experimental and control group were homogeneous or equal in their writing skill.

The Implementation

In this study the researcher divided the classes into two groups, those were 11 MIPA 2 as the experimental group who Group Statistics

\begin{tabular}{|c|r|r|r|r|}
\hline Group & N & Mean & \multicolumn{1}{c|}{$\begin{array}{c}\text { Std. } \\
\text { Deviation }\end{array}$} & $\begin{array}{c}\text { Std. Error } \\
\text { Mean }\end{array}$ \\
\hline $\begin{array}{c}\text { Score Experimental } \\
\text { Group }\end{array}$ & 30 & 60.67 & 3.594 & .656 \\
Control Group & 30 & 62.40 & 3.587 & .655 \\
\hline
\end{tabular}

was taught by using graphic organizer with schoology, while the class of 11 MIPA 3 as the control group who was taught by only using graphic organizer. This research was conducted for six meetings. The first meeting was pre-test, the second until the fifth meeting did the treatment and the last meeting was post-test. 


\section{Post-Experiment}

After the researcher gave the experimental group and control group treatments, the researcher conducted the post-test for both of the groups. The test item is in form of writing test. In the posttest, the researcher prepared four themes among others are Bullying, Learning English, Global Warming and Environment. After that, the teacher asked the students to choose one of the themes and then the students wrote an analytical exposition text based on the theme. The next step was the researcher analyzed the data after doing the post test.

Hypothesis Testing

The researcher input the data by using SPSS program between the experimental group which got the treatment by using graphic organizer with schoology and control group which got the treatment by only using graphic organizer. The result of Independent Sample T-test can be seen in the table below:
Group Statistics

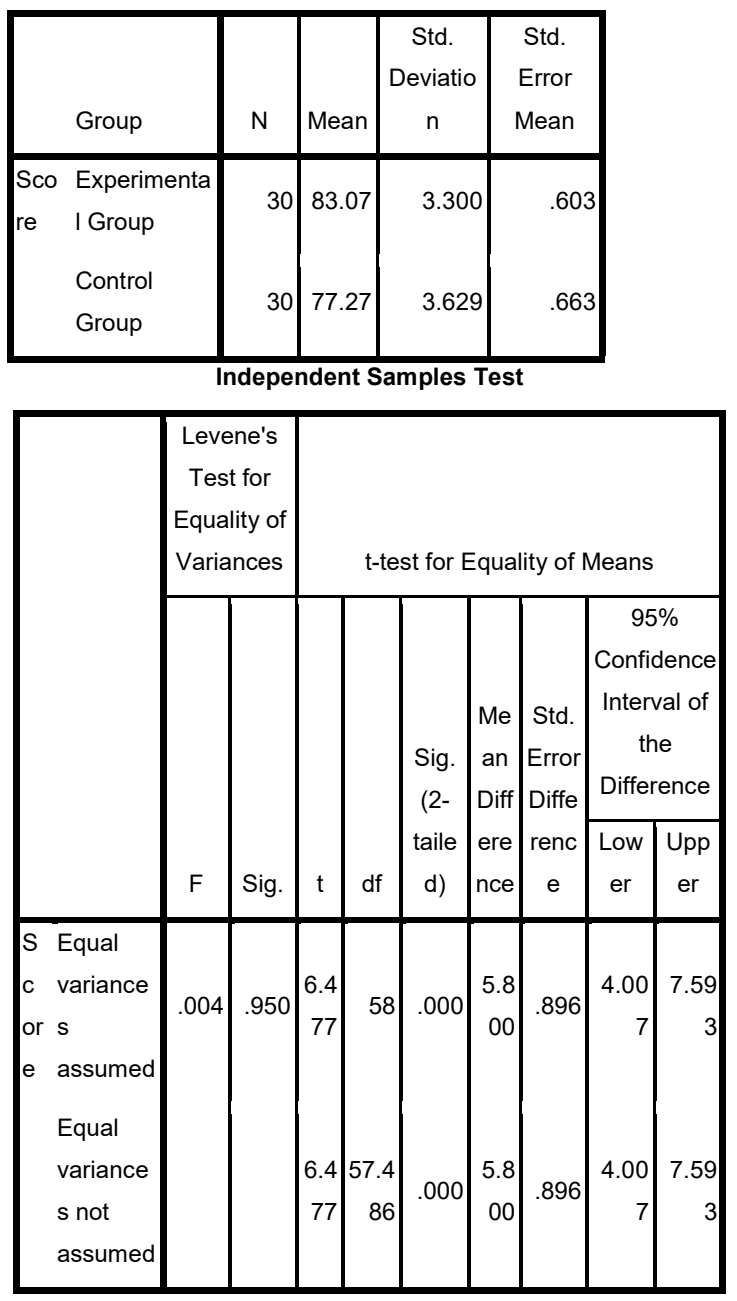

From the table above, it can be seen that the result of mean experimental group was 83.07 and control group was 77.27. It showed that the mean was gained by the experimental class which was higher than the control class. It was indicated that the treatment was working. However, to see the significance of the mean difference, Independent t-test computation was conducted. The T-test was calculated to find out the comparison from two means between experimental group and control group. 
The table above showed that the value of Sig.(2-tailed) was 0.000 in critical value for $5 \%$ level. It means that the significance value was less than $5 \%$ or $(0.000<0.05)$. So, the null hypothesis could be rejected. It can be concluded that there is enough evidence to conclude that the use of graphic organizer with schoology better than only using grapic organizer in student's writing skill at eleven grade of Senior High School. Besides that, the researcher also analyzed the data based on each aspect of writing. The data can be seen in the table below:

\begin{tabular}{|l|l|l|l|}
\hline No. & $\begin{array}{l}\text { Aspect of } \\
\text { Writing }\end{array}$ & $\begin{array}{l}\text { Pre- } \\
\text { Test }\end{array}$ & $\begin{array}{l}\text { Post- } \\
\text { Test }\end{array}$ \\
\hline 1. & Content & 18.73 & 24.23 \\
\hline 2 & Organization & 11.10 & 17.28 \\
\hline 3. & Vocabulary & 12.19 & 17.50 \\
\hline 4. & Language Use & 14.69 & 19.84 \\
\hline 5. & Mechanics & 4.02 & 4.34 \\
\hline
\end{tabular}

From the table above, it can be showed that result of five aspects in writing skill for post-test higher than the score of pre-test. Firstly, the score of pre-test in content aspect was 18.73 while the post-test was 24.23. Secondly, the score of pre-test in organization aspect was 11.10 while the post-test was 17.28. Thirdly, the score of pre-test in vocabulary aspect was 12.19 while the post-test was 17.50 . Fourthly, the score of pre-test in language use was 14.69 while the post-test was 19.84. Lastly was mechanics, the score of pre-test from this aspect was 4.02 while the post-test was 4.34 .

\section{Discussion}

The aim of this study was to investigated the effect of graphic organizer with schoology on students' writing skill. The researcher would like to know the significant effect of using graphic organizer with schoology for student's writing skill in eleventh grade at MA Masyhudiyah Giri. The researcher chose graphic organizer with schoology because the researcher want to combine strategy and media to give something new for the students. In this case the researcher used schoology where schoology is Learning Management System (LMS). As we know that in this age technology becomes center of the world. All of people especially teenagers interested in using it.

Furthermore, based on the study that has been conducted by the researcher, it showed that teaching writing using graphic organizer with schoology made the teaching and learning process became effective. It was make graphic organizer with schoology gave significant effect on students' writing skill. By using graphic organizer with schoology the students could produce good writing. The students also can get the conducive atmosphere in classroom so that the students actively involved in teaching learning process. Based on the 
data that have been analyzed, it can be seen that the mean score was increased. For the experimental class, the mean increased from 60.67 become 83.07. This finding is supported by Mahmudah \& Jamilah (2015), they said that graphic organizer can make the writing became better. Graphic organizer could make the writings had content that acceptable and relevant.

Graphic organizer also can help the ideas organize properly. Then, Miller (2011) said that graphic organizer can help to direct the writer in the details and specific ordering of ideas needed that can make the writer produce good writing. Besides that, Mayer (1995) said that graphic organizer can help the writers focus on a topic and can maintain their ideas when they are writing based on information or ideas in the desired order. Ruddell (2001) also said that graphic organizer can provide a preliminary organizational plan of the ideas that students have chosen, then can connect these ideas and the supporting details so it can make the students write proficiently. In other side Mutia (2018) said that schoology has possitive impact in writing skill. Schoology has the feature to upload videos or image so that it can help the writer find the information about the topic that they will write. It help the students get more vocabulary and enjoyed to write. Then, Aminoto, Tugiyo \& Pathoni Hairul (2014) said that schoology becomes an interesting learning medium because Schoology combines some features of the Learning Management System (LMS) and some of the features of social networking (Social Network). Greenhow, Robelia, \& Hughes (2009) also added that schoology is more favorable to students. Because schoology has a great feature. One of the features is resources. In the resources feature, the students can draw there. Furthermore, Ardi, P. (2017) has a recommendation to use Schoology in English language learning and teaching because schoology can make the students actively involved in the learning process and can give the students meaningful and relevant English learning experiences in the 21 st century. In addition, based on Krisyandi (2016) schoology helps teachers in classroom management. Schoology can create conducive atmosphere in classroom so the teacher can achieve the effective and efficient language teaching. It can make the students success on learning and they can get a good outcome.

From the result of computation, it can be concluded that graphic organizer with schoology have positive effect on students' writing skill. By using graphic organizer with schoology the students can get good result in their writing. This does not only give advantages to the students but also the teacher who can make the class more enjoyable and not monotonous. It 
shows that, the theory from previous studies that implement the use of graphic organizer is still relevant even better after the researcher combine it with schoology. The result of this experiment is still showing that the use of graphic organizer with schoology can increase the students' writing skill.

\section{CONCLUSION AND SUGGESTION}

\section{Conclusion}

Based on the result of the study, it can be concluded that there is a positive significant effect of using Graphic Organizer with Schoology on students' writing skill at eleventh grade of MA Masyhudiyah Giri. It shows that the use of Graphic Organizer with Schoology help the students to increase their aspects of writing, among these are content, organization, vocabulary, language use and mechanics so it makes the students can produce a good writing. Schoology also has a feature to upload videos, this is help students to get background knowledge about the theme or topic that they will write so they are easier to fill their map framework to create their graphic organizer. Not only that, Graphic Organizer with Schoology is also can make the students enjoy a lot in teaching-learning process. Furthermore, Graphic organizer with Schoology help the teacher in designing good classroom management. This make the teacher can achieve the effective and efficient language teaching. So the students get a good result in writing.

\section{Suggestion}

Based on the result of the study, the researcher would like to give some suggestions:

1. Suggestion for English Teacher

The findings of this study can support English teacher at MA Masyhudiyah Giri to consider of using Graphic Organizer with Schoology in writing class. By using that, the students can achieve their goal in writing. It because Graphic Organizer with Schoology can help the students to arrange organizational plan of their ideas when they write in an interesting way. Besides that, the teacher is expected to always pay attention in development student's writing skill. So the teacher can find out how the students progress in writing. It will help the teacher in planning further learning activities so that the teaching process becomes better. The teacher also should always create the good atmosphere in class because it can make the students actively involved to follow the teaching and learning activity. This can also foster the student's motivation to study so that the teacher can reach the effective and efficient language teaching and then the result is the students can get a good achievement in writing.

2. Suggestion for Students 
The researcher suggest for the students to practice their writing by using Graphic Organizer with Schoology. Because the findings showed that Graphic Organizer with Schoology can help the students have a good writing. Besides it, the students should realize that they have important role in teaching and learning process. For that, the students are hoped to enganged in the whole activities and give full attention to the teacher. On the other hand, the students expected to lot of practice to write although there is no task form the teacher in order to get better performance in writing.

\section{Suggestion for Future Researcher}

For the future researcher, the researcher suggest to do further research about Graphic Organizer with Schoology in teaching because it is good to use in learning process. The future researcher can implement Graphic Organizer with Schoology in different way to develop other skill such as reading skill.

\section{REFERENCES}

Al-Jarrah, T.M. et al. 2018. EFL Students'

Attitude Toward Using

Metacognitive Strategies in

Writing. English Language

Teaching, 11(10), 1916-4742 \&

1916-4750.doi:

10.5539/elt.v11n10p162
Apriliani, A., Asib, A., \& Ngadiso. 2019.

Schoology as a Learning Media

Platform for Writing Skill. $3^{\text {rd }}$

English Language and Literature

International Conference

(ELLiC), Volume 3.

Ardi, P. 2017. Promoting Learner

Autonomy through Schoology M-

Learning Platform in an Eap

Class at an Indonesian University.

Teaching English with

Technology, 17(2), 55-76.

Ariyani, N. 2013. Developing a Rubric for Portfolio Assessment in Writing of Grade VII Students at SMP Negeri 15 Yogyakarta. English

Language Education Department

Faculty of Languages and Arts

Yogyakarta State University.

Asrobi, M., \& Prasetyaningrum, A. 2017.

Trait Based Assessment on

Teaching Writing Skill for EFL

Learners. English Language

Teaching, 10(11), 1916-4742 \&

1916-4750. doi:

10.5539/elt.v10n11p199

Biswas, S. 2013. Schoology-Supported

Classroom Management: A

Curriculum Review. Northwest

Journal of Teacher Education, Volume 11. 
Exdriko, Y., Tavriyanti, L., \& Refnita, L.

2014. The Teaching of Writing A

Descriptive Text Using Clustering

Technique for Bung Hatta

University Students. English

Department the Faculty of

Teacher Training and Education

Bung Hatta University.

González, C.A.M., Anderson, C.E., \&

Medina, LC. 2018. Graphic

Organizers Support Young L2

Writers' Argumentative Skills.

Gist Education and Learning

Research Journal. ISSN 1692-

5777, pp. 6-33.

Goss, P.A. 2009. The Influence of Graphic

Organizers on Students ' Ability

to Summarize and Comprehend

Science Content Regarding the

Earth's Changing Surface.

University of Central Florida.

Herdi., Yasin, A., \& Syarif, H. 2014.

Improving Students' Writing Skill

by Using Graphic Organizer at

the Second Year Students English

Education Department Faculty of

Education and Teachers Training

Lancang Kuning University

Pekanbaru.

Hindasah., A. 2018. Improving Students'

Writing Skill for an Invitation
Text Using Raft Strategy in MTs

Nurul Huda Sedati. English

Teacher Education Department

Faculty of Tarbiyah and Teacher

Training Sunan Ampel State

Islamic University Surabaya.

Huy, NT. 2015. Problems Affecting

Learning Writing Skill of Grade

11 at Thong Linh High School.

Asian Journal of Educational

Research, 2311-6080.

Inayah, N., \& Nanda, RP. 2016. Efforts to Improve Writing Skills of High

School Students. Studies in

English Language and Education, $3(1), 50-64$.

Indahtriyani, OE., Sada, C., \& Sutapa, G. 2015. The Scientific Approach in Teaching Writing by Using

Guided Writing Based On Curriculum 2013. Jurnal

Pendidikan dan Pembelajaran.

Irawan, VT., Sutadji, E., \& Widiyanti. 2017. Blended Learning Based on Schoology: Effort of Improvement Learning Outcome and Practicum Chance in Vocational High School. Cogent Education. 
Irawati, L., Lestari, S., \& Wahyuni, T, 2014. Implementasi Sandwich

Graphic Organizer untuk

Meningkatkan Kemampuan

Menulis Esei Mahasiswa

Semester III. Jurnal Penelitian

$L P P M$.

Joshua, J.W.N., Swastika, I.P.A., \& Estiyanti, N.M. 2015. The Effectiveness of E-Learning Implementation Using Social Learning Network Schoology on Motivation \& Learning Achievement. Jurnal Nasional Pendidikan Teknik Informatika, Volume 5.

Kristanti, Y. 2016. The Effectiveness of Using Graphic Organizer in Teaching Writing to the Seventh Grade Students of MtsN Bagor in the Academic Year 2015/2016.

Krisyandi, Y.B. 2016. Teachers'

Perception Towards The Use of

Schoology in the Pronounciation

Class at Satya Wacana Christian University.

Kurniawati, D., \& Kurniawan, T.O. 2017.

Using Highlighted Journal

Strategy in Teaching Analytical

Exposition Text. English
Education: Jurnal Tadris Bahasa Inggris.

Low, P. 2017. E-learning Implementation in Foundation English Class:

Learners' Perspectives and Learning Achievement. International Journal of Computer Theory and Engineering, 9(4). doi: 10.7763/IJCTE.2017.V9.1153

Lungu, L. Senior Secondary

English Language Syllabus.

Curriculum Development Centre.

Maharani, M.M. 2018. Graphic Organizers to Improve Students' Writing on Recount Paragraphs. Metathesis: Journal of English Language Literature and Teaching, 2 (2), $211-221$. doi:10.31002/metathesis.v2i2.942

Mahmudah, I., \& Jamilah 2016. Using Graphic Organizers to Improve the Writing Skill of IX Grade Students of SMPN 9 Yogyakarta in the Academic Year Of 20142015. Universitas Negeri Yogyakarta.

Man, CY. Promoting Journal

Writing to Enhance Students' English Competence and 
Learning Motivation in a

Secondary School in Hong Kong .

SKH Holy Carpenter Secondary

School.

Miller, S.A. 2011. Using Graphic

Organizers to Increase Writing

Performance. State University of

New York at Fredonia.

Muhib, M.S. 2015. Improving The Writing Skills of the English Article Writers' Training of Pluswriter Company Through the Use of Tiered Activities. English Education Department Faculty of Languages and Arts Yogyakarta State University.

Muhtia, A., Suparno., \& Sumardi. 2018. Blended Learning Using Schoology as an Online Learning Platform. $2^{\text {nd }}$ English Language and Literature International Conference (ELLiC), Vol. 2, 2579-7263 \& 2579-7549.
Mustaqiyah, K. 2016. The Effectiveness of Using Graphic Organizers to Teach Writing of Descriptive Text (An Experimental Research at the Tenth Grade of MAN 02 Semarang in the Academic Year of 2016/2017). Undergraduate (S1) Thesis, UIN Walisongo.

Mutia, A.S. 2018. The Implementation of Schoology E-Learning Web to Improve Students' Paragraph Writing at the Eight Grade Students of MTSN Surakarta II.

Novariana, H., Sumardi., \& Tarjana, SS. 2018. Senior High School Students' Problems in Writing. English Language and Literature International Conference, Vol. 2, 2579-7263 \& 2579-7549. .2001. The Use of Graphic Organizers to Enhance Thinking Skills in the Learning of Economics. Education Department.

Pablo, J.C.I., \& Lasaten, R.C.S. 2018. Writing Difficulties and Quality of Academic Essays of Senior High School Students. Asia Pacific Journal of Multidisciplinary Research, 6(4), 46-57. 
Putra, L.G.R. . Modul Pelatihan

Pemanfaatan E-Learning.

Universitas Darussalam Gontor.

Qishta, F.M. 2017. The Effectiveness of Using Pictures on Developing Sentence Writing Skills for the Seventh Graders in the Governmental Schools in Rafah. Deanship of Postgraduate Studies and Scientific Research.

Rahmatullah, M. 2016. The Relationship between Learning Effectiveness, Teacher Competence and Teachers Performance Madrasah Tsanawiyah at Serang, Banten, Indonesia. Higher Education Studies, 6(1), 1925-4741 \& 1925475X. doi: 10.5539/hes.v6n1p169

Rosalina, M. 2018. Analysis the use of Schoology E-Learning Towards Students' Learning Motivation Enhancement in STKIP Surya. Indonesian Journal of Science and Education, 2(1), 89-95, doi: 10.31002/ijose.v2i1.614

Rubiyah., Ping, M. T., \& Syamdianita. 2018. Implementing Concept Mapping to Improve Students' Descriptive Writing Ability. Language and Language Teaching Journal, Volume 21.
Rukmini, D., \& Saputri, L.A.D.E. 2017. The Authentic Assessment to Measure Students' English Productive Skills Based on 2013 Curriculum. Indonesian Journal of Applied Linguistics. Volume 7.

Rusin. W. 2003. Graphic Organizers: What are the Effects of Writing, Attitudes Towards, and Usage of Graphic Organizers in a Fourth Grade Classroom. The College at Brockport: State University of New York.

Salem, A.A.M.S. 2013. The Effect of Using Writer's Workshop Approach on Developing Basic Writing Skills (Mechanics of Writing) of Prospective Teachers of English in Egypt. English Language Teaching, 6(7), 19164742 \& 1916-4750. doi:10.5539/elt.v6n7p33

Sari, M.K. 2017. An Analysis of Students' Problem in Writing Recount Text. JURNAL EDUCATIVE: Journal of Educational Studies.

Setyono, B. 2014. Approaches in Teaching Writing Designed by High School English Teachers in Indonesia. International Journal 
of Sciences: Basic and Applied

Research.

Sianna, S., \& Syawal, S. 2017. The Implementation of POEW in Teaching Writing. International Journal of Language Education, $1(1), 51-61$.

Sicat, A.S. 2015. Enhancing College Students' Proficiency in Business Writing Via Schoology.

Tigowati, T., Efendi, A., \& Budiyanto, CW. 2017. The Influence of Elearning Use to Student Cognitive Performance and Motivation in Digital Simulation Course. Indonesian Journal of Informatics Education, 1(2), 2549-0389. Volume 1.

Wibowo, A.B. 2013. Improving Writing Skill by Using Process Writing Approach for Grade X Students of SMA N 1 Kasihan Bantul Yogyakarta in the Academic Year Of 2012/ 2013. Universitas Negeri Yogyakarta.

Wibowo, V. 2016. Students' Perception of Using Schoology in an Argumentative Writing Class.

Wulandari, S. 2017. The Effect of Using Know-Want to Know-Learned
International Journal of

Education and Research, 3(1), 2201-6333 \& 2201-6740.

Tayib, A.M. 2015. The Effect of Using Graphic Organizers on Writing (A Case Study of Preparatory College Students at Umm-AlQura University). International Journal of English language Teaching. Volume 3.

(KWL) Strategy on Sudents' Reading Chomprehension to the Eighth Grade Students' of MTs Ma'arif Balong in Academic Year 2016/2017. The state Institute of Islamic Studies Ponorogo.

Yavani, Z. 2018. Improving Students' Writing Skill through Graphic Organizer in Process Writing, 2579-8170 \& 2549-5089.

Yulianti, D. B. 2018. Learning Strategies Applied by the Students in Writing English Text. Journal on English as a Foreign Language, Vol. 8, No. 1.

Zulaikah, Z., \& Afas, M.Z. 2016. Teaching Descriptive Paragraph Writing by Using "Semantic Mapping Strategy" to the Tenth Grade Students of MA Nurul Huda 
Sukaraja. Jurnal Darussalam:

Jurnal Pendidikan, Komunikasi

dan Pemikiran Hukum Islam. 1:

175-191. 